\title{
Management of Rice (Oryza sativa L.) Sheath Blight (Rhizoctonia solani Kuhn) and Sheath Rot (Sarocladium oryzae Sawada) through Seed Bio-Priming
}

\author{
M.R. Shekhada ${ }^{1 *}$, V.A. Patil ${ }^{2}$, A.S. Savaliya ${ }^{1}$ and M.D. Sangani ${ }^{1}$ \\ ${ }^{1}$ Department of Plant Pathology, N. M College of Agriculture, Navsari Agricultural \\ University, Navsari-396 450, Gujarat, India \\ ${ }^{2}$ Main Rice Research Centre, SWMRU, Navsari Agricultural University, \\ Navsari-396 450, Gujarat, India \\ *Corresponding author
}

A B S T R A C T

Keywords

Rice, Seed biopriming, Sheath rot, Sheath blight, Disease incidence and Disease severity

Article Info

Accepted:

15 July 2018

Available Online:

10 August 2018
Results obtained in the experiments conducted to find out effect of seed bio-priming on management of sheath blight and sheath rot diseases of rice in field condition revealed that seed bio-primed with Trichoderma harzianum applied at imbibition was proved to be an excellent bio-agent to manage sheath blight (Rhizoctonia solani) with minimum disease incidence (25.67\%) and severity (21.63\%) whereas Pseudomonas fluorescens applied at imbibition significantly manage sheath rot (Sarocladium oryzae) with minimum disease incidence (28.67\%) and severity (23.41\%). Similarly, significantly higher grain yield $\left(4505 \mathrm{~kg} \mathrm{ha}^{-1}\right)$ was recorded in seed bioprimed with $P$. fluorescens applied at imbibition.

\section{Introduction}

Rice (Oryza sativa L.) is the world's second most important cereal crop grown throughout the world and is a staple food crop of 60 per cent of the world's population. Rice productivity facing numerous problem, mostly related to the environmental and food safety issues. Diseases are the major constraint in economic crop production as they inflict heavy losses. Seed-borne fungal diseases viz., sheath blight and sheath rot are important in reducing the yield and seed quality of rice. The intensive uses of chemical pesticides has been identified contributes to the numerous recent environmental problems. Seed treatment systems that will enhance efficacy of biological agents are needed and "bio- 
priming" is one such attempt being made in this direction. Seed bio-priming is treating seed with bio-agents and incubating under warm and moist condition until just prior to radical emergence (Harman and Taylor, 1988).

\section{Materials and Methods}

The field experiment was laid out during kharif 2017 in Randomized Block Design (RBD) with ten treatments (Table 1) and each treatment replicated thrice using rice $c v$. GR11 at Main Rice Research farm, NAU, Navsari on management of rice sheath blight and sheath rot by using seed bio-priming method.

\section{Bio-priming (applied at imbibition)}

Ten gram of talc formulation of the bio-agents along with $0.1 \mathrm{~g}$ gum arabic were used as adhesive was mixed in $25 \mathrm{ml}$ of water. Pre- treated rice seed (surface sterilized with $0.1 \%$ $\mathrm{HgCl}_{2}$ for 2 to $3 \mathrm{~min}$. followed by three washing with water) was soaked in this slurry for 24 hours at room temperature and then dried on blotter paper at room temperature. Seeds without any treatment served as control (Srivastava et al., 2010).

\section{Bio-priming (after imbibition)}

Seeds of rice were imbibed in aerated water (50 g seed per $500 \mathrm{ml}$ water) for 24 hours and then dried at room temperature. Formulation of the bio-agent in talc along with $0.1 \mathrm{~g}$ gum arabic was dusted on seed after seed was imbibed and dried. Seeds without any treatment served as control. The data were recorded as Per cent Disease Incidence (PDI), Per cent Disease Severity (PDS) and grain yield.

\section{Disease incidence $(\%)$}

$$
\text { Disease incidence }(\%)=\frac{\text { Number of diseased plants }}{\text { Total number of plants }} \times 100
$$

\section{Disease severity (\%)}

The disease severity was measured by adopting 0-9 scale (Table 2 and 4) using standard evaluation system for rice developed by International Rice Research Institute (IRRI, 2002).

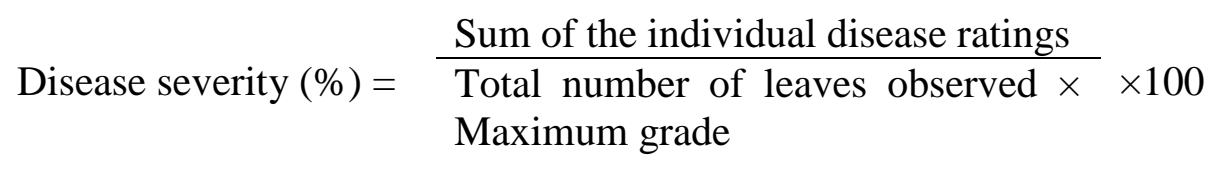

\section{Grain yield ( $\left.\mathrm{kg} \mathrm{ha}^{-1}\right)$}

The grain yield was recorded from net plot area after harvest and converted in to hectare basis and data were statistically analyzed.

\section{Results and Discussion}

The data presented in Table 3 and Fig. 1 and 2 revealed that all the treatments significantly reduced the sheath blight and sheath rot incidence and severity as compared to control. Among all the treatments, $T$. harzianum applied at imbibition was found significantly superior with minimum sheath blight incidence (25.67\%) and severity (21.63\%) which was found statistically at par with $T$. viride applied at imbibition (26.33\%) and (22.37\%), P. fluorescens applied at imbibition 
(27.00\%) and (23.11\%) and T. viride applied after imbibition $(28.00 \%)$ and $(24.30 \%)$. The next best treatment in order of merit was $B$. subtilis applied at imbibition (34.33\%) and (29.33\%) followed by P. fluorescens applied after imbibition $(35.00 \%)$ and $(31.85 \%), T$. harzianum applied after imbibition (35.67\%) and $(32.59 \%), \quad B$. subtilis applied after imbibition $(36.00 \%)$ and $(32.89 \%)$ and primed seeds with hydration (37.33\%) and (33.93\%). The maximum disease incidence $(38.00 \%)$ and severity $(34.22 \%)$ was observed in control.

Whereas, minimum sheath rot incidence $(28.67 \%)$ and severity $(23.41 \%)$ was recorded in $P$. fluorescens applied at imbibition it was found statistically at par with $T$. harzianum applied at imbibition (29.33\%) and (25.04\%), T. viride applied at imbibition $(30.00 \%)$ and (26.07\%) and P. fluorescens applied after imbibition $(31.33 \%)$ and $(28.30 \%)$. The next best treatment in order of merit was $B$. subtilis applied at imbibition (35.67\%) and (30.67\%) followed by $T$. harzianum applied after imbibition $(36.67 \%)$ and $(31.11 \%)$, T. viride applied after imbibition (37.00\%) and (32.00\%), B. subtilis applied after imbibition $(37.33 \%)$ and $(34.81 \%)$ and primed seeds with hydration $(40.33 \%)$ and $(36.30 \%)$. The maximum disease incidence $(41.67 \%)$ and severity $(37.48 \%)$ was observed in control.

The results of grain yield presented in Table 3 and Fig. 2 revealed that significantly highest grain yield (4505 $\mathrm{kg} \mathrm{ha}^{-1}$ ) was harvested in plot treated with $P$. fluorescens applied at imbibition which was found statistically at par with $T$. harzianum applied at imbibition (4412 $\mathrm{kg} \mathrm{ha}^{-1}$ ), T. viride applied at imbibition (4282 $\mathrm{kg} \mathrm{ha}^{-1}$ ) and B. subtilis applied at imbibition (3984 $\left.\mathrm{kg} \mathrm{ha}^{-1}\right)$.

Table.1 Treatment details for seed bio-priming

\begin{tabular}{|c|c|c|}
\hline $\begin{array}{l}\text { Tr. } \\
\text { No. }\end{array}$ & & Treatment \\
\hline $\mathbf{T}_{1}$ & : & Bio-priming (T. viride applied at imbibition) \\
\hline $\mathbf{T}_{2}$ & : & Bio-priming (T. viride applied after imbibition) \\
\hline $\mathbf{T}_{\mathbf{3}}$ & : & Bio-priming (T. harzianum applied at imbibition) \\
\hline $\mathbf{T}_{4}$ & : & Bio-priming (T. harzianum applied after imbibition) \\
\hline $\mathbf{T}_{5}$ & : & Bio-priming (P. fluorescens applied at imbibition) \\
\hline $\mathbf{T}_{6}$ & $:$ & Bio-priming ( $P$. fluorescens applied after imbibition) \\
\hline $\mathbf{T}_{7}$ & : & Bio-priming (B. subtilis applied at imbibition) \\
\hline $\mathbf{T}_{8}$ & : & Bio-priming (B. subtilis applied after imbibition) \\
\hline $\mathbf{T}_{9}$ & : & Hydropriming (Water only) \\
\hline $\mathbf{T}_{10}$ & : & Control (Without any treatment) \\
\hline
\end{tabular}

Table.2 Disease severity scale for sheath blight (IRRI, 2002)

\begin{tabular}{|c|l|}
\hline Scale & Description \\
\hline $\mathbf{0}$ & No infection \\
\hline $\mathbf{1}$ & 1 to 20 per cent area of leaves/plant part infected \\
\hline $\mathbf{3}$ & 21 to 30 per cent area of leaves/plant part infected \\
\hline $\mathbf{5}$ & 31 to 45 per cent area of leaves/plant part infected \\
\hline $\mathbf{7}$ & 46 to 65 per cent area of leaves/plant part infected \\
\hline $\mathbf{9}$ & 66 to 100 per cent area of leaves/ plant part infected \\
\hline
\end{tabular}


Table.3 Effect of seed bio-priming on incidence of rice diseases and yield

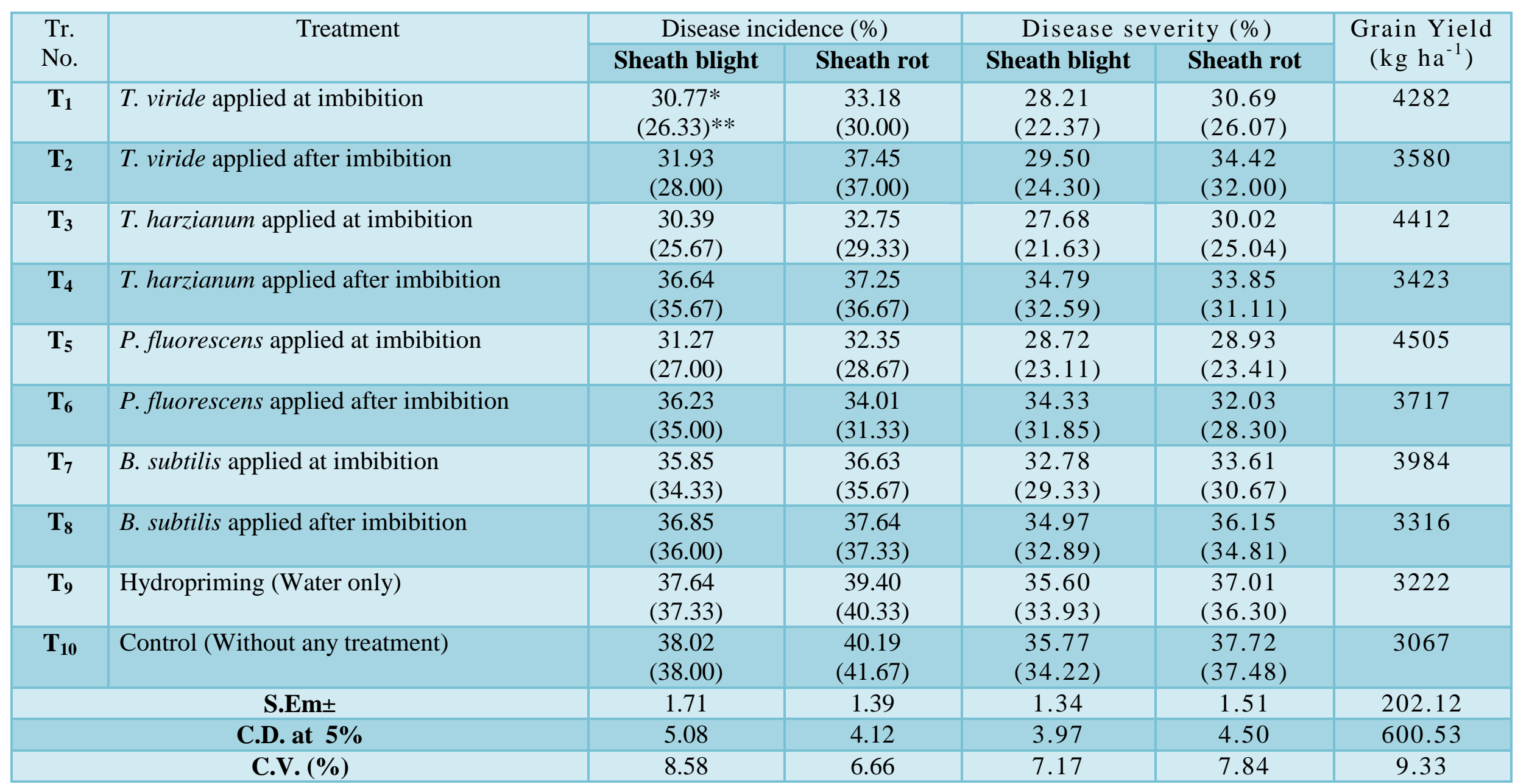

*Figure outside parenthesis are arc sine transformed value **Figures in parentheses are original value 
Fig.1 Effect of seed bio-priming on incidence of sheath blight and sheath rot

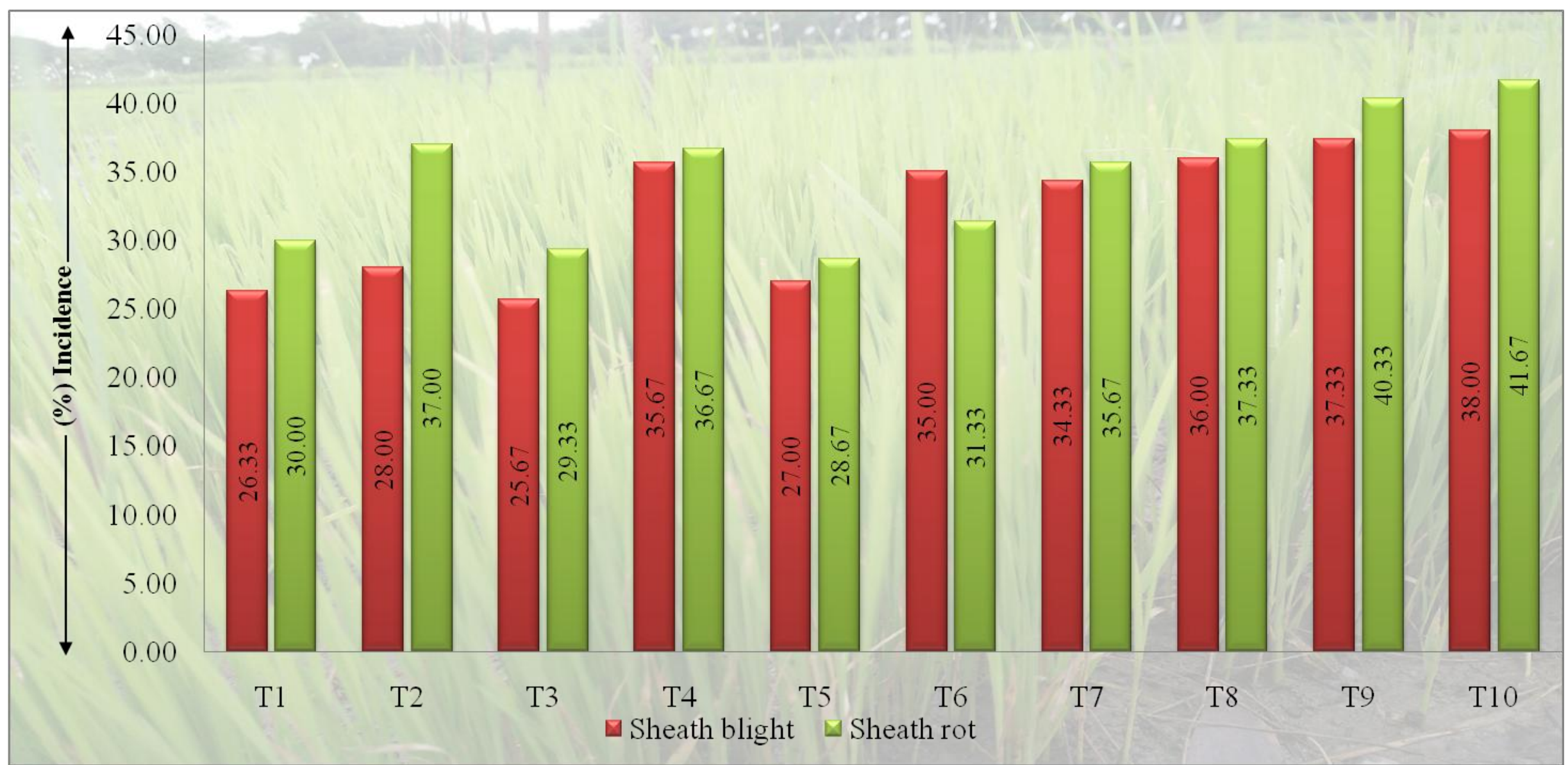

Treatments

$\mathbf{T}_{\mathbf{1}}=T$. viride applied at imbibition

$\mathbf{T}_{4}=T$. harzianum applied after imbibition

$\mathbf{T}_{5}=P$. fluorescens applied at imbibition

$\mathbf{T}_{\mathbf{7}}=$ B. subtilis applied at imbibition $\quad \mathbf{T}_{\mathbf{1 0}}=$ Control

$\mathbf{T}_{\mathbf{2}}=T$. viride applied after imbibition

$\mathbf{T}_{\mathbf{6}}=P$. fluorescens applied after imbibition

$\mathbf{T}_{8}=B$. subtilis applied after imbibition

$\mathbf{T}_{\mathbf{3}}=T$. harzianum applied at imbibition 
Fig.2. Effect of seed bio-priming on severity of sheath blight, sheath rot and yield of rice

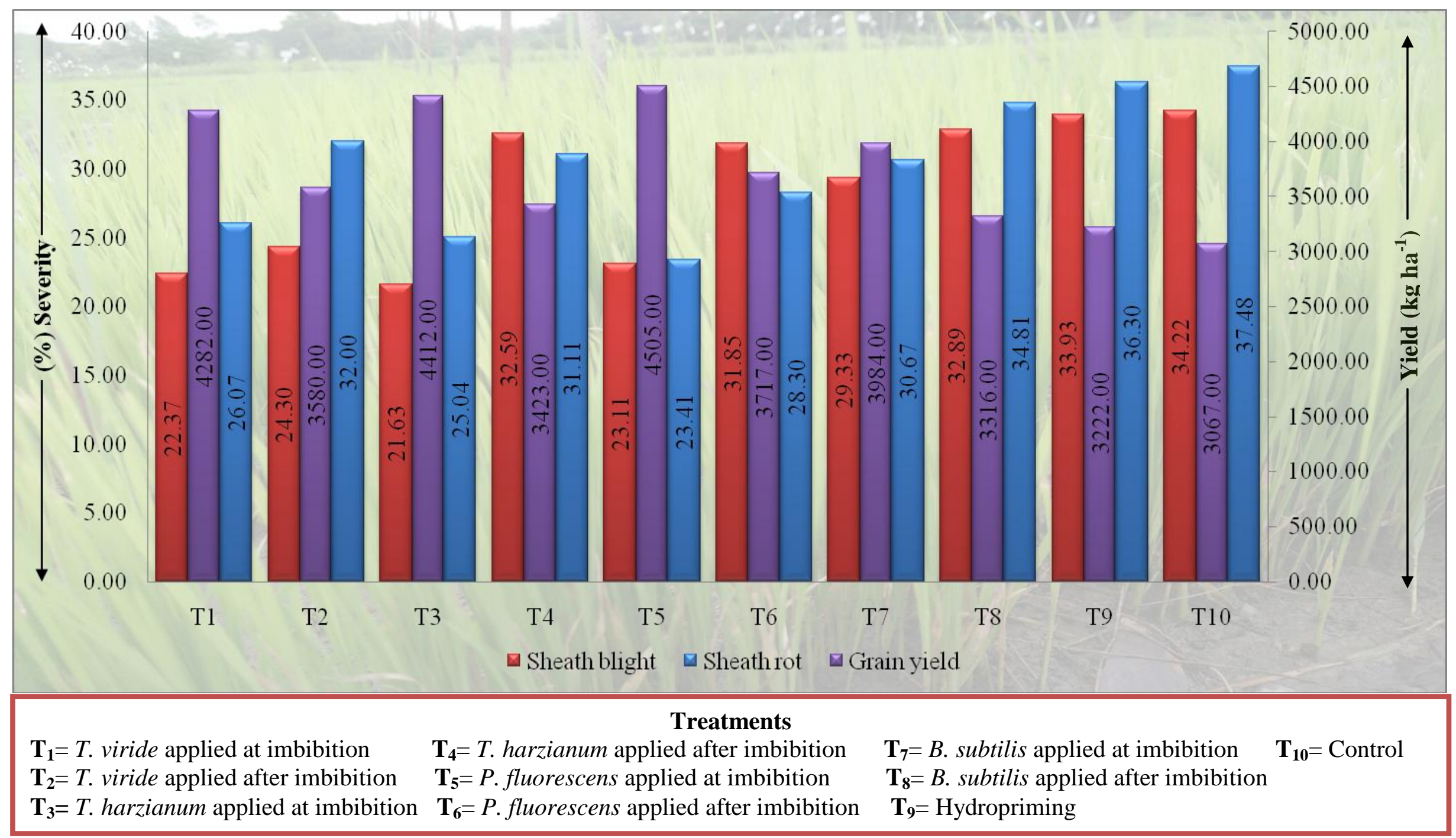


Table.3 Disease severity scale for sheath rot (IRRI, 2002)

\begin{tabular}{|c|c|}
\hline Scale & Description \\
\hline $\mathbf{0}$ & No lesion/ spot on flag leaf sheath. \\
\hline 1 & $\begin{array}{l}\text { Spots visible on the tillers upon very careful examination (less than } 1 \text { per cent flag } \\
\text { leaf sheath area covered). }\end{array}$ \\
\hline 3 & $\begin{array}{l}\text { Spots visible on the tillers upon careful examination ( } 1 \text { to } 5 \text { per cent flag leaf sheath } \\
\text { area covered). }\end{array}$ \\
\hline 5 & Spots easily visible on the tillers (6 to 25 per cent flag leaf sheath area covered). \\
\hline 7 & $\begin{array}{l}\text { Spots present on almost whole the tillers parts ( } 26 \text { to } 50 \text { per cent flag leaf sheath area } \\
\text { covered). }\end{array}$ \\
\hline 9 & $\begin{array}{l}\text { Spots very common on whole the tillers parts ( } 51 \text { to } 100 \text { per cent flag leaf sheath area } \\
\text { covered) death of plants common, reduced severe yield loss. }\end{array}$ \\
\hline
\end{tabular}

The next best treatment in order of merit was $P$. fluorescens applied after imbibition (3717 $\left.\mathrm{kg} \mathrm{ha}^{-1}\right), T$. viride applied after imbibition (3580 kg ha ${ }^{-1}$ ), T. harzianum applied after imbibition (3423 $\left.\mathrm{kg} \mathrm{ha}^{-1}\right)$, B. subtilis applied after imbibition (3316 kg ha ${ }^{-1}$ ) and seeds primed with hydration (3222 $\left.\mathrm{kg} \mathrm{ha}^{-1}\right)$. The lowest grain yield (3067 $\left.\mathrm{kg} \mathrm{ha}{ }^{-1}\right)$ was observed in control.

The results obtained in present study were found in harmony with the findings of earlier workers, Gopalakrishnan and Valluvaparidasan (2006) observed that $P$. fluorescens showed the lowest per cent of sheath rot incidence and severity and Mougy and Kader (2008) noticed that seed biopriming with $T$. harzianum gave the lowest per cent sheath blight incidence and severity. These results were also in agreement with those of other workers, Jain and Lore (2014) and Suman et al. (2017).

The present study concludes that out of ten treatments tested against sheath blight and sheath rot of rice through seed bio-priming. The minimum sheath blight incidence $(25.67 \%)$ and severity $(21.63 \%)$ was found in $T$. harzianum applied at imbibition it was found statistically at par with $T$. viride applied at imbibition, $P$. fluorescens applied at imbibition and $T$. viride applied after imbibition whereas minimum sheath rot incidence $(28.67 \%)$ and severity $(23.41 \%)$ was found in $P$. fluorescens applied at imbibition it was found statistically at par with $T$. harzianum applied at imbibition, $T$. viride applied at imbibition and P. fluorescens applied after imbibition.

\section{References}

Gopalakrishnan, C. and Valluvaparidasan, V. (2006). Seed-borne bio-control agents for the management of rice sheath rot caused by $S$. oryzae. Journal of Biological Control, 20(2): 197-204.

Harman, G. E. and Taylor, A. G. (1988). Improved seedling emergence by species of Pythium in relation to soil moisture. Phytopathology, 80: 13171322.

IRRI. (2002). Standard Evaluation System for rice. The International Rice Testing Programme. International Rice Research Institute, Manilla, Philippines. Pp: 20-21.

Jain, J. and Lore, H. S. (2014). Efficacy of $P$. fluorescens formulations in the sheath blight disease management of rice. Journal of Eco-friendly Agriculture, 9(1): 65-68.

Mougy-el, N. S. and Kader abdel, M. M. (2008). Long-term activity of bio- 
priming seed treatment for biological control of faba bean root rot pathogens. Australasian Plant Pathology, 37(5): 464-471.

Srivastava, R., Khalid, A., Singh, U. S. and Sharma, A. K. (2010). Evaluation of arbuscular mycorrhizal fungus. Fluorescent Pseudomonas and Trichoderma harzianum formulation against Fusarium oxysporum f. sp. lycopersici for the management of tomato wilt. Biological Control, 53: 24-31.

Suman, B., Gopal, A. V., Reddy, R. S., Triveni, S. and Nissipaul, M. (2017). Study the efficacy of $P$. fluorescens against sheath blight in rice by R. solani. International Journal of Current Microbiology and Applied Sciences, 6(4): 2581-2589.

\section{How to cite this article:}

Shekhada, M.R., V.A. Patil, A.S. Savaliya and Sangani, M.D. 2018. Management of Rice (Oryza sativa L.) Sheath Blight (Rhizoctonia solani Kuhn) and Sheath Rot (Sarocladium oryzae Sawada) through Seed Bio-Priming. Int.J.Curr.Microbiol.App.Sci. 7(08): 2787-2794. doi: https://doi.org/10.20546/ijcmas.2018.708.293 